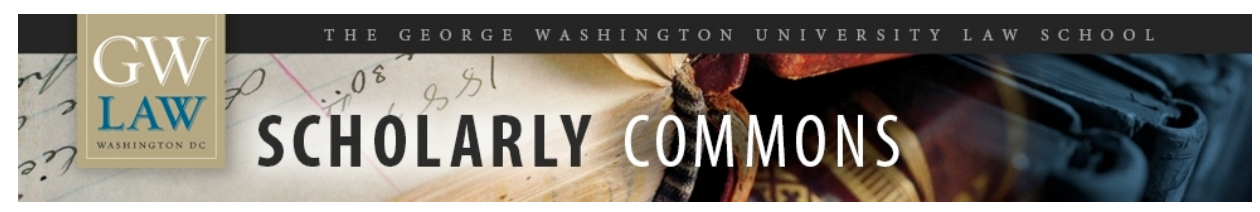

\title{
Kiobel, Subject Matter Jurisdiction, and the Alien Tort Statute
}

Bradford R. Clark

George Washington University Law School, bclark@law.gwu.edu

Follow this and additional works at: https://scholarship.law.gwu.edu/faculty_publications

Part of the Law Commons

\section{Recommended Citation}

This Article is brought to you for free and open access by the Faculty Scholarship at Scholarly Commons. It has been accepted for inclusion in GW Law Faculty Publications \& Other Works by an authorized administrator of Scholarly Commons. For more information, please contact spagel@law.gwu.edu. 


\title{
Kiobel, Subject Matter Jurisdiction, and the Alien Tort Statute
}

\author{
Anthony J. Bellia Jr. \& Bradford R. Clark ${ }^{\dagger+}$
}

The Supreme Court is currently reviewing the Second Circuit's decision in Kiobel v. Royal Dutch Petroleum, a case holding that federal courts lack jurisdiction under the Alien Tort Statute ("ATS") over claims against corporations. ${ }^{1}$ Although the parties have focused on issues of corporate liability under the ATS, there is a logically antecedent question of subject matter jurisdiction that the Court should decide before considering corporate liability. All of the parties in Kiobel-whether corporate or individual-are aliens. Understood in its full legal and historical context, the ATS was a jurisdictional statute that did not apply to suits between aliens. In Sosa v. Alvarez-Machain, the Supreme Court sought to interpret the ATS in accordance with the expectations of the First Congress. ${ }^{2}$ If the Court adheres to this goal in Kiobel, then it should conclude that it lacks statutory subject matter jurisdiction over the case.

This understanding of the ATS avoids the substantial constitutional question that would arise under Article III if ATS jurisdiction were interpreted to reach suits between aliens. Because all of the parties in Kiobel are aliens, subject matter jurisdiction under Article III must rest on something other than diversity of citizenship. (Article III diversity jurisdiction extends the federal judicial power to suits between an alien and a U.S. citizen, not to suits between aliens. ${ }^{3}$ ) Because the case does not involve admiralty, ambassadors, states, or the United States, the only potential candidate is federal question jurisdiction pursuant to the Arising Under Clause. There are several impediments, however, to finding such jurisdiction. In Sosa, the Supreme Court held that "the ATS is a jurisdictional statute creating no new causes of action." ${ }^{{ }^{4}}$ Because the ATS "is in terms only jurisdictional," ${ }^{5}$ it would be difficult to conclude that cases brought under the statute arise under the Constitution, laws, or treaties of the United States within the meaning of Article III. At a minimum, reading the ATS to confer jurisdiction over suits between aliens would raise substantial constitutional questions under Article III. These questions can be avoided, however, by

\footnotetext{
$\dagger$ Professor of Law and Notre Dame Presidential Fellow, Notre Dame Law School.

†† William Cranch Research Professor of Law, The George Washington University Law School.

621 F.3d 111 (2d Cir. 2010).

542 U.S. 692 (2004).

"The judicial Power shall extend ... to Controversies ... between a State, or the Citizens thereof, and foreign States, Citizens or Subjects." U.S. ConST. art III, § 2.

4542 U.S. at 724.

$5 \quad$ Id. at 712 .
} 
reading the statute in accordance with its original understanding to restrict federal jurisdiction to suits by aliens against U.S. citizens. ${ }^{6}$

As enacted in 1789, the ATS provided that "the district courts ... shall [] have cognizance, concurrent with the courts of the several States, or the circuit courts, as the case may be, of all causes where an alien sues for a tort only in violation of the law of nations or a treaty of the United States." ${ }^{\prime}$ The statute identifies the plaintiff as an alien, but does not specify the nationality of the defendant. Nor does the statute specify the meaning of "a tort only in violation of the law of nations." In 1980, lower federal courts began the practice of reading the ATS expansively to allow foreign citizens to sue other foreign citizens for violations of modern customary international law that occurred outside the United States. ${ }^{8}$ In Sosa, the Supreme Court took a more restrictive approach. Without addressing the propriety of the party alignment or subject matter jurisdiction, the Court rejected a claim by a Mexican citizen suing another Mexican citizen as outside the scope of the ATS. Specifically, the Court concluded that Jose Francisco Sosa's claim for arbitrary detention did not constitute a tort in violation of the law of nations within the meaning of the statute. Although the Court interpreted the statute to leave the door "open to a narrow class of international norms [existing] today," it stressed the need for "judicial caution when considering the kinds of individual claims that might implement the jurisdiction conferred by the early statute." ${ }^{\prime 10}$ According to the Court, the ATS should be interpreted in accordance with the views of the First Congress. Under this approach, "federal courts should not recognize private claims under federal common law for violations of any international law norm with less definite content and acceptance among civilized nations than the historical paradigms familiar when [the ATS] was enacted." ${ }^{11}$

Neither the broader approach initially endorsed by lower federal courts nor the more restrictive approach subsequently adopted by Sosa fully captures the original meaning and purpose of the ATS. The ATS, understood in historical context, was meant to cover a narrower set of party alignments than those allowed by lower federal courts but a broader range of torts than those identified in Sosa. Read in light of Article III, the common law forms of action applicable to intentional torts against aliens, and the background law of nations principles that informed the statute, the ATS is best read to have restricted suits to those against U.S. citizens but to have allowed aliens to sue for any intentional tort involving force against their person or personal property. At the time, only such "torts" committed by U.S. citizens

6 Our analysis of the ATS in this Essay is drawn substantially from our recent article discussing the history of the statute in much greater detail. See Anthony J. Bellia Jr. and Bradford R. Clark, The Alien Tort Statute and the Law of Nations, 78 U. Chi. L. Rev. 445 (2011). Judiciary Act of $1789 \S 9,1$ Stat. 73, 76-77, codified as amended at 28 U.S.C. $\S 1350$. See, e.g., Filartiga v Pena-Irala, 630 F.2d 876, 878 (2d Cir. 1980).

542 U.S. at 729.

10 Id. at $725-28$.

11 Id. at 732 . 
against aliens would have been understood to violate "the law of nations."

In 1789 , every nation had a duty to redress certain violations of the law of nations committed by its citizens or subjects against other nations or their citizens. Such violations included interfering with the rights of ambassadors, violating safe conducts, impairing neutral use of the high seas, and committing intentional torts against the citizens of another nation. If a nation failed to redress such violations, then it became responsible to the other nation under the law of nations and gave the other nation just cause for war. The First Congress was undoubtedly aware of these principles and enacted several statutory provisions-including the ATS-in order to comply with the United States' obligations under the law of nations to redress violations by its citizens. This context helps to illuminate the original meaning and purpose of the ATS.

In 1789, the United States was a weak nation seeking to avoid conflict with foreign nations. The Constitution was designed to enhance the United States' ability to comply with its various obligations under the law of nations-and thus prevent conflict with other nations. For example, Article I gave Congress power to define and punish offenses against the law of nations. ${ }^{12}$ The First Congress exercised this power to enact important federal criminal prohibitions designed to deter and punish certain violations of the law of nations, including violations of the rights of ambassadors and violations of safe conducts. In addition, Article III authorized federal court jurisdiction over a variety of civil cases implicating the law of nations and U.S. foreign relations, including admiralty disputes, cases affecting ambassadors, and controversies between foreign citizens and citizens of the United States. The Judiciary Act of 1789 implemented this jurisdiction by authorizing federal courts to hear suits by ambassadors, admiralty and maritime disputes, and controversies between aliens and U.S. citizens. Within the last category, the Act gave federal circuit courts general foreign diversity jurisdiction (with a $\$ 500$ amount in controversy requirement) andby virtue of the ATS-federal district courts jurisdiction over alien claims "for a tort only in violation of the law of nations or a treaty of the United States" (with no amount in controversy requirement). Without the ATS, the amount in controversy requirement would have prevented federal courts from hearing most claims for intentional torts committed by U.S. citizens against aliens. Such torts, however, constituted violations of the law of nations that the United States had an obligation to redress. Thus, by enacting the ATS, the First Congress enabled the United States to remedy an important category of law of nations violations committed by U.S. citizens against aliens.

Although the practice has been largely forgotten today, a nation became responsible under the law of nations for injuries that its citizens inflicted on aliens if it failed to provide an adequate means of

12 U.S. CONST. art. I, § 8, cl. 10. 
redress-by punishing the wrongdoer criminally, extraditing the offender to the aggrieved nation, or imposing civil liability. Failure to redress such injuries in one of these ways gave the alien's home nation just cause for war. In the aftermath of the Revolutionary War, members of Congress did not believe that they could rely upon states to redress injuries suffered by British subjects at the hands of Americans. To ensure that the United States would not violate the law of nations, the First Congress enacted both criminal and civil statutes to redress harms inflicted by U.S. citizens against aliens. Because early federal criminal jurisdiction did not clearly encompass all such harms, the ATS operated as a fail-safe provision. The ATS gave British subjects (and all other aliens) a right to sue Americans in federal court for torts that, if not redressed through a civil or criminal action, would render the United States responsible for its citizens' violations of the law of nations. By authorizing civil redress under the ATS, the United States simultaneously signaled to other nations its intent to comply fully with its obligations under the law of nations and established a self-executing means of avoiding military reprisals for the misconduct of its citizens.

The First Congress did not have the same incentives to authorize the adjudication of tort suits between aliens in federal court. In this regard, it is useful to analyze suits between aliens based on where the tort occurred. First, consider violence between aliens that took place in the United States. Unlike violence against aliens by U.S. citizens, violence by aliens against other aliens was not directly imputed to the United States under the law of nations if the United States failed to redress it. Under the law of nations, the United States did not have the same obligation to redress such violence as it did to redress violence by US citizens. Nor is it clear that such alien-alien violence occurred with any frequency in the 1780s. If suits of this kind arose, moreover, state courts were available to hear them. There does not appear to be any evidence that states failed to adjudicate such suits fairly (unlike suits by aliens against U.S. citizens). Accordingly, even assuming that the United States had an obligation to redress violence in its territory by one alien against another, redress in state court would have satisfied that obligation. Absent evidence that such claims arose frequently or that state courts failed to adjudicate them fairly, Congress had no obvious reason to assign them to federal courts. Had it wished to do so, moreover, it could not have relied on foreign diversity jurisdiction. Rather, it would have had to employ "arising under" jurisdiction by creating a federal cause of action.

Second, consider violence between aliens that occurred in foreign nations (a routine scenario in modern ATS cases, including Kiobel). The law of nations imposed no obligation on the United States to provide aliens with a forum for adjudicating such claims against one another. Thus, failure to adjudicate such claims would not have subjected the United States to reprisals by foreign nations. Indeed, at the time the ATS was adopted, adjudication of such claims arguably would have infringed upon the territorial sovereignty of 
foreign nations under the law of nations. Under these circumstances, the First Congress had no reason to authorize-and good reason to exclude-suits between aliens in federal court for acts occurring in other nations.

The limited nature of federal judicial power under the Constitution also suggests that the ATS was meant to encompass only claims by aliens against U.S. citizens. Article III extends the judicial power to only nine categories of cases and controversies. The first three categories are defined by reference to the subject matter of the case. The last six categories are defined by reference to the identities of the parties. Suits by aliens against U.S. citizens fall within diversity jurisdiction over controversies "between a State, or the Citizens thereof, and foreign States, Citizens or Subjects. ${ }^{13}$ By contrast, suits by aliens against other aliens do not fall within Article III's diversity jurisdiction. Thus, to uphold jurisdiction over such suits, one would have to conclude that they constitute cases "arising under this Constitution, the Laws of the United States, and Treaties made, or which shall be made, under their Authority." ${ }^{14}$ At the time the ATS was enacted, however, there was no "federal common law." Rather, the law of nations was understood to be general law. ${ }^{15}$ After the Constitution was ratified and the ATS enacted, judges and other public officials sharply debated whether federal courts had power in the exercise of their Article III jurisdiction to adopt and apply a municipal common law of the United States (including those parts of the law of nations incorporated by the common law). Ultimately, this question was resolved in 1812 when the Supreme Court decided that the constitutional structure precludes federal courts from unilaterally recognizing and applying common law crimes on behalf of the United States.

For these reasons, the First Congress would not have understood an alien claim "for a tort only in violation of the law of nations" to arise under the Constitution, Laws, and Treaties of the United States. Moreover, although scholars continue to debate aspects of Sosa's precise holding, the Supreme Court affirmed, as a matter of historical understanding, that "the ATS is a jurisdictional statute creating no new causes of action." ${ }_{16}$ On this understanding, the statute merely gave aliens a federal forum to adjudicate common law claims for law of nations violations that happened to fall within Article III jurisdiction, such as controversies between a citizen or subject of a foreign state and a citizen of an American state. The ATS

13 U.S. ConsT. art. III, § 2, cl. 1.

14 Id.

15 Of course, Congress could enact a federal cause of action between aliens for particular international law violations, as it did in the Torture Victim Protection Act of 1991, and give federal courts "arising under" jurisdiction over such claims. The First Congress, however, would not have understood the ATS to create a federal cause of action or to confer subject matter jurisdiction on federal courts over claims between aliens.

16542 U.S. at 724 
did not create an independent cause of action arising under federal law.

These considerations suggest that the ATS was originally enacted to enable the United States to remedy a specific, but important, law of nations violation-the intentional infliction of harm by a U.S. citizen upon the person or personal property of an alien. In the parlance of the time, such harms constituted "torts" "in violation of the law of nations." Understanding the ATS as one of the means employed by the First Congress to fulfill the United States' duties under the law of nations is consistent with the Constitution's allocation of powers to conduct war and foreign relations. Historically, this allocation of powers has led the Supreme Court to read federal statutes to avoid conflict with foreign nations absent a clear indication from the political branches that they intended to initiate such conflict. The Supreme Court famously endorsed this approach in Murray $v$ Schooner Charming Betsy, ${ }^{17}$ and the same constitutional concerns animate the Court's adherence to traditional sovereignty-respecting rules like the act of state doctrine. By understanding the ATS as a means of satisfying the United States' obligations under the law of nations, courts would avoid usurping the constitutional prerogatives of the political branches.

Courts and scholars have advanced various claims about the ATS, but none has fully recovered the original meaning of the statute in its historical context. Some scholars have suggested that the ATS was originally understood to authorize federal court jurisdiction over all alien tort claims for law of nations violations, regardless of the citizenship of the parties. These theories are too broad because they not only fail to account for the jurisdictional limitations of Article III but also contradict important principles of the law of nations, which the ATS was meant to uphold. Others have argued that the ATS was intended to give federal courts jurisdiction over only particular kinds of paradigmatic law of nations violations-for example, violations of safe conducts or certain kinds of admiralty torts. Similarly, the Supreme Court itself has concluded that the ATS encompasses only a narrow class of international torts closely analogous to the three international crimes recognized by Blackstone. ${ }^{18}$ These theories are too narrow because they do not include certain basic tort claims by aliens against Americans that members of the Founding generation would have understood the ATS to encompass in order to satisfy the United States' basic obligations under the law of nations. Still other scholars have contended that history reveals interpretive presumptions that courts should apply to the ATS, including a presumption that courts should interpret the ATS expansively in favor of alien-alien claims because the Founders aspired to give the law of nations broad effect in the

\footnotetext{
176 U.S. (2 Cranch) 64, 118 (1804).

18 Sosa, 542 U.S. at 724-25. According to the Court, these categories consisted of "torts corresponding to Blackstone's three primary offenses [against the law of nations]: violation of safe conducts, infringement of the rights of ambassadors, and piracy." Id. at 724. See WILLIAM BLACKSTONE, 4 COMMENTARIES ON THE LAWS OF ENGLAND *68.
} 
United States. These theories, however, are anachronistic. Had courts interpreted the ATS too broadly in 1789, they could have violated distinct principles of the law of nations recognizing the territorial sovereignty of independent states. Even today, adjudication of suits between aliens arising abroad risks friction with other nations.

In 1789, the most natural way to read the ATS, given its full legal and historical context, was as a grant of jurisdiction to federal district courts to hear common law tort claims by aliens against United States citizens who used force to injure the person or personal property of an alien. Contrary to some anachronistic modern theories, the ATS did not recognize such tort claims as a matter of "federal common law." True federal common law did not emerge until the twentieth century. The First Congress expected federal courts exercising jurisdiction under the ATS to employ state common law forms of action under the Process Act and to apply any other governing state rules of decision under the Rules of Decision Act. By authorizing such adjudication in federal court, the ATS prevented the United States from becoming responsible for wrongs committed by its citizens against aliens. In light of this background, the ATS is best understood as a self-executing, fail-safe measure that prevented giving other nations just cause for war or reprisals against the United States based on the misconduct of its citizens against aliens. Extending the ATS to suits between aliens would have been not only unnecessary, but counterproductive and probably unconstitutional. The United States was not responsible for harms inflicted by one alien against another, and it had no obligation to remedy harms inflicted abroad by one alien on another. To the contrary, adjudicating such claims might have been regarded as an interference with the territorial sovereignty of other nations-itself a violation of the law of nations. Moreover, giving federal courts such jurisdiction (without creating a new federal cause of action) would have exceeded the limits of Article III. Thus, interpreting the ATS to confer jurisdiction only over claims by aliens against U.S. citizens is not only the most plausible reading of the statute, but the only reading that both prevents friction with other nations and avoids serious constitutional questions under Article III.

Although Sosa involved a suit between Mexican nationals, the Supreme Court did not consider or decide whether the ATS confers jurisdiction over suits between aliens, or whether such jurisdiction would violate Article III. First, the Court concluded that Alvarez had not alleged a tort "in violation of the law of nations" within the meaning of the statute. Given this statutory holding, the Court had no need to consider either the appropriateness of the party alignment under the ATS or the constitutional issue that such an alignment would have raised. Second, as originally filed, Sosa included U.S. defendants. Accordingly, the district court had an independent constitutional and statutory basis for subject matter jurisdiction over Alvarez's original claims against the United States 
(based on the FTCA) ${ }^{19}$ and over Alvarez's claims against the U.S. DEA agents (based on diversity of citizenship). ${ }^{20}$ Because Alvarez's tort claims against Sosa, the United States, and the DEA agents all arose from a common nucleus of operative fact, the claims originally formed part of a single constitutional "case" for purposes of Article III. ${ }^{21}$ It follows that the federal courts-including the Supreme Court-had Article III power to adjudicate the case even after the US defendants were dismissed. Accordingly, Sosa did not present (and the Court did not decide) the questions whether the ATS and Article III permit federal courts to adjudicate claims solely between aliens. ${ }^{22}$ Indeed, the Court has made clear that its opinions cannot be read to decide questions of subject-matter jurisdiction sub silentio.

Kiobel squarely presents these unanswered questions of subject matter jurisdiction. The plaintiffs and the defendants are all aliens. No U.S. citizens or corporations have ever been parties to the case. If the Court concluded that the ATS confers jurisdiction only over suits by aliens against US citizens, then the Court could avoid both the Article III and the corporate liability issues. Because the partyalignment issue under the ATS is a question of subject matter jurisdiction, it cannot be waived by the parties and may be raised at any time in the proceedings by the parties or the court. Thus, before the Court considers corporate liability under the ATS, logic suggests that it should decide first whether the ATS even applies to suits between aliens.

If the Court decides that the ATS does not apply to suits between aliens, then it will likely never have occasion to decide the thorny question of corporate liability under the ATS. Under the express terms of 28 U.S.C. \$1332, federal courts already have jurisdiction over suits by aliens against U.S. corporations provided that the amount in controversy is greater than $\$ 75,000.00$. Although the diversity statute (like the ATS) was silent as to corporate citizenship when originally enacted in 1789, Congress subsequently amended the diversity statute to provide that U.S. corporations are

19 See 28 U.S.C. $§ 1346$ (b)(1) (granting district courts exclusive jurisdiction over "civil actions on claims against the United States" for wrongs caused by wrongful or negligent acts of federal employees acting in the course of their duties).

20 See 28 U.S.C. $§ 1332(\mathrm{a})(2)$ (granting jurisdiction over suits between "citizens of a State and citizens or subjects of a foreign state").

21 See United Mine Workers of America v Gibbs, 383 U.S. 715, 725 (1966).

22 See 28 U.S.C. $§ 1367$ (a) (granting supplemental jurisdiction over cases that form part of "the same case or controversy"). Nor did the Court conclude that Alvarez's ATS claim arose under the Constitution, laws, and treaties of the United States within the meaning of Article III. The Court repeatedly stressed that the ATS is purely a jurisdictional statute that creates no federal cause of action. See Sosa, 542 US at 724. In addition, the Court rejected Justice Scalia's assertion that "a federal-common-law cause of action of the sort the Court reserves discretion to create would 'arise under' the laws of the United States, not only for purposes of Article III but also for purposes of statutory federal-question jurisdiction." Id. at $745 \mathrm{n} *$ (Scalia concurring in part and concurring in the judgment). According to the Court, its position did not imply that "the grant of federal-question jurisdiction would be equally as good for our purposes as $§ 1350$." Id. at 731 n.19 (majority). Indeed, the Court acknowledged that although its holding was "consistent with the division of responsibilities between federal and state courts after Erie, ... a more expansive common law power related to 28 U.S.C. $§ 1331$ might not be." Id. 
citizens of their state of incorporation and the state in which they have their principal place of business. Thus, aliens would have to rely on the ATS for jurisdiction only in the unlikely event that they were suing a U.S. corporation for less than the $\$ 75,000$ amount in controversy requirement. Because the ATS is jurisdictional, little turns on whether an alien sues a U.S. corporation in federal court under the ATS or the diversity statute. At the time of its enactment, ATS jurisdiction was understood to encompass intentional acts of violence by U.S. citizens against aliens. In 1789, the Process Act required federal courts exercising either ATS jurisdiction (with no amount in controversy requirement) or foreign diversity jurisdiction (with a $\$ 500$ amount in controversy requirement) to employ the common law forms of action used by the states in adjudicating such tort claims. Section 34 of the Judiciary Act of 1789 (the Rules of Decision Act) additionally required federal courts to apply any other applicable state rules of decision. Following Erie and the abolition of the forms of action by the Federal Rules of Civil Procedure, there are at least three ways in which the Court might try to apply the ATS in light of its original meaning. Under any alternative, federal courts should use the same rules of decision to adjudicate a tort claim by an alien against a U.S. citizen regardless of whether the claim is brought under ATS or foreign diversity jurisdiction.

First, the Court might regard jurisdiction under the ATS to be all but obsolete because vanishingly few torts committed by U.S. citizens against aliens now violate the law of nations, and such torts are no longer attributable to the United States if not redressed. (Failure to provide aliens with fair access to court could give rise to a denial of justice claim, but such claims are not addressed by the ATS.) From this perspective, the ATS gives federal courts jurisdiction over a set of cases that no longer exist. Even under this interpretation, however, aliens who suffer intentional injuries to person or personal property at the hands of U.S. citizens still would have recourse in federal court. Rather than invoke ATS jurisdiction, the alien would have to employ foreign diversity jurisdiction, where there is an amount in controversy requirement but express statutory authority to name U.S. corporations as defendants.

Second, the Court might interpret the ATS to continue to give federal courts jurisdiction to hear claims involving intentional torts of violence by U.S. citizens against aliens because these are the claims that the ATS originally encompassed. Under this approach, courts would essentially treat the relevant statutory text-"tort only in violation of the law of nations" - as a term of art or shorthand that referred to suits by aliens against U.S. citizens for intentional harms to an alien's person or personal property. Under this interpretation, federal courts would apply the same law in ATS cases as they would apply in foreign diversity jurisdiction-that is, federal procedural rules and the state or foreign substantive law applicable under state conflicts rules. Again, as the ATS was originally understood, municipal (i.e. domestic) law provided the rule of decision in ATS 
cases. The "tort" the ATS encompassed was "in violation of the law of nations" not because international law created a liability in one person to another for a tort injury, but rather because the offender's nation would be responsible for the tort under the law of nations if it failed to redress it under domestic law. Accordingly, in 1789 the same municipal law would apply whether a tort was brought in ATS jurisdiction or foreign diversity jurisdiction. The same would be true today. Under this alternative, the same law would apply whether the case was brought in ATS or foreign diversity jurisdiction. The only difference would be the amount in controversy requirement and the diversity statute's explicit instructions to treat corporations as citizens of certain states.

Third, the Court might perpetuate the erroneous suggestion in Sosa that the First Congress understood the ATS to encompass a limited category of tort liabilities that international law itself creates. Even under this interpretation, the same law should apply whether the alien brings the "international tort" claim in foreign diversity or ATS jurisdiction. If some tort liabilities created by customary international law qualify as federal common law causes of action, they should be cognizable in either ATS or foreign diversity jurisdiction if brought by an alien against a U.S. citizen. If brought in foreign diversity jurisdiction, there would no issue of corporate liability under the ATS. Regardless of Sosa's error in this regard, however, state or foreign law more likely would supply the rule of decision in a tort claim brought by an alien against a U.S. citizen. No matter the rule of decision in a foreign diversity case, the ATS corporate liability issue would not arise.

Kiobel also raises the question whether ATS jurisdiction applies to torts committed outside the territorial jurisdiction of the United States. In our view, the First Congress would have understood foreign diversity and ATS jurisdiction to extend to claims by aliens against U.S. citizens regardless of whether the claim arose within the territorial jurisdiction of the United States. In 1789, it was well established that an alien could bring a tort or contract claim arising in one nation in the courts of the defendant's home nation because such actions were "transitory," not "local." ${ }^{23}$ The principle underlying transitory actions was that the cause of action followed the defendant from one jurisdiction to another. Courts did not hesitate to exercise jurisdiction over such actions unless the plaintiff and defendant were both aliens. ${ }^{24}$ Courts exercised jurisdiction over transitory actions because the cause of action was understood to follow the defendant into the court's jurisdiction. It is uncontroversial that federal courts may exercise foreign diversity jurisdiction over tort claims by aliens against U.S. citizens for acts occurring outside the United States. It should be no more controversial for federal courts to exercise ATS jurisdiction over

23 See Bellia \& Clark, supra note 6, at 469. See generally Printz v. United States, 521 U.S. 898 (1997) (describing transitory causes of action).

24 Bellia \& Clark, supra note 6, at 482-83. 
intentional tort claims by aliens against U.S. citizens for acts occurring outside the United States. If the amount in controversy in such an ATS suit exceeds $\$ 75,000$, the alien may also bring the claim in foreign diversity jurisdiction.

If the Court does not address the antecedent jurisdictional question in Kiobel of whether the ATS extends to claims between aliens, the question will remain open in pending cases and the Court will likely face it in a future case as judges and litigants begin to address it explicitly. For example, in Sarei v. Rio Tinto, ${ }^{25}$ an en banc panel of the Ninth Circuit Court of Appeals recently divided on this jurisdictional question. Judge Ikuta-in a dissent joined by Judges Kleinfeld, Callahan, and Bea-argued that federal courts lack subject matter jurisdiction under the ATS over claims between aliens. Judge Ikuta concluded that Sosa had not resolved this question because there the Court had supplemental jurisdiction over the claim under the ATS. Furthermore, she explained, the Court could not resolve the jurisdictional question sub silentio. Finally, she observed that federal courts have an obligation to consider their subject matter jurisdiction at any stage of the proceeding, whether or not the parties have raised it. Similarly, in Mwani v. United States ${ }^{26}$ pending in U.S. District Court for the District of Columbia, Magistrate Judge Facciola recently stayed all proceedings in an ATS case between aliens to await, among other things, whether Kiobel addresses the antecedent jurisdictional question whether the ATS extends to claims between aliens. If the Court declines to address this jurisdictional question on the current certiorari petition in Kiobel, the question may persist in Kiobel itself in further proceedings. Were the Kiobel Court to proceed directly to determine that corporations may be liable in ATS cases and remand the case, the jurisdictional question would remain open on remand in the Second Circuit.

As originally understood, the ATS provided a particularly important species of foreign diversity jurisdiction-jurisdiction over claims by aliens against U.S. citizens for intentional acts of violence against person or personal property. ${ }^{27}$ In 1789, the First Congress would have understood the importance of giving federal courts jurisdiction over such cases without regard to the amount in controversy because of their importance under the law of nations. Today, most such claims will seek more than $\$ 75,000$ in damages, and thus will fall within the federal courts' uncontroversial diversity jurisdiction. Because foreign diversity jurisdiction and the municipal rules of decision that generally apply in such cases unremarkably extend to corporations, the Court likely will never have to decide the ATS corporate liability question if it instead addresses the antecedent jurisdictional question in Kiobel whether the ATS extends to actions between aliens.

25 Nos. 02-56256, 02-56390, 09-56381, 2011 WL 5041927 (9th Cir. Oct. 25, 2011).

26 No. 99-125 (D. D.C. Jan. 10, 2012) (order staying proceedings).

27 Bellia \& Clark, supra note 6, at 524-25. 